\title{
Holocene deglaciation and climate history of the northern Antarctic Peninsula region: a discussion of correlations between the Southern and Northern Hemispheres
}

\author{
Christian HJort, ${ }^{1}$ Svante Björck, ${ }^{2}$ Ólafur Ingólfsson, ${ }^{3}$ Per Möller ${ }^{1}$ \\ ${ }^{1}$ Department of Quaternary Geology, Lund University, Sölvegatan 13, S-223 62 Lund, Sweden \\ ${ }^{2}$ Department of Geology, University of Copenhagen, Øster Voldgade 10, DK-1350 Copenhagen, Denmark \\ ${ }^{3}$ Department of Geology, University of Gothenburg, Guldhedsgatan 5A, S-413 81 Gothenburg, Sweden
}

\begin{abstract}
The chronology of post-Last Glacial Maximum deglaciation in the northern Antarctic Peninsula region is discussed. It is concluded that, contrary to what was earlier believed, the deglaciation process here was largely out-of-phase with that in the Northern Hemisphere. Although, for global eustatic reasons, the marine-based glaciers may have retreated simultaneously with ice-melting in the Northern Hemisphere, the land-based glaciers retreated only slowly during the first half of the Holocene, about 9000-5000 BP. This may have been due either to increased precipitation counterweighing ablation or to delayed warming. A distinct but rather brief glacial readvance took place around $5000 \mathrm{BP}$, probably caused by a period of renewed cooling. It was followed by the Holocene climatic optimum, about 4000-3000 BP. This warm "hypsithermal" period thus came much later than its equivalent in the Northern Hemisphere, but it roughly coincided with the Milankovitchean Holocene insolation maximum for these southern latitudes.
\end{abstract}

\section{INTRODUCTION}

In the early days of Quaternary studies in the Antarctic Peninsula region (including the South Shetland Islands and the islands in the western Weddell Sea), it was generally believed that the post-Last Glacial Maximum (Wisconsinan, Weichselian, etc.) deglaciation had a timing similar to that in the Northern Hemisphere. The onset of deglaciation of the presently ice-free areas was assumed to have begun before $10000 \mathrm{BP}$, and the oldest isostatically elevated sediments related to the deglaciation were dated to about 9000 BP (e.g. John and Sugden, 1971; Sugden and John, 1973). These ideas prevailed until the beginning of this decade (e.g. Clapperton, 1990), although hints of a more complicated picture had been published several years before (Rabassa, 1983, 1987).

Work carried out on land in the South Shetlands and on the islands in the western Weddell Sea during the 1980s and 1990s suggests a different deglaciation pattern than "the Northern Hemisphere concept". Studies of glacial deposits and their relation to isostatically elevated marine sediments, and of lake-sediment and moss-bank cores, suggest that (1) the initial deglaciation of the presently ice-free lowland areas in the Antarctic Peninsula region took place gradually between about 9000 and $5000{ }^{14} \mathrm{C}$ years BP, and (2) that a distinct but rather short-lived glacial readvance culminated around or shortly after $5000 \mathrm{BP}$, followed (3) by the Holocene climatic optimum ("hypsithermal") between about 4000 and 3000 BP. Thereafter, (4) climate gradually approached present conditions, as illustrated by a number of mostly restricted neoglacial oscillations, including a correlative of the Northern Hemisphere's Little Ice Age readvance.
It also seems that most of the data which were earlier interpreted according to the "Northern Hemisphere concept" may be fitted into the new paradigm. This is especially the case when the empirically derived marine reservoireffect correction of -1200 years (e.g. Gordon and Harkness, $1992)$ is applied, instead of the smaller corrections (700850 years) used in earlier works.

The present paper gives a brief overview of the available terrestrial dataset, and tries to put some of the "older" data into the modern concept.

Table 1. Radiocarbon datings regarded as closely postdating the last deglaciation of different areas in the northern Antarctic Peninsula region (Fig. 1). The dates on marine organisms are corrected for a reservoir effect of -1200 years (Gordon and Harkness, 1992)

\begin{tabular}{|c|c|c|c|}
\hline Locality & Age BP & Dated sample & Source \\
\hline $\begin{array}{l}\text { Jurasee, Fildes } \\
\text { Peninsula, King } \\
\text { George Island }\end{array}$ & $8700 \pm 300$ & Limnic moss? & $\begin{array}{l}\text { Mäusbacher } \\
\text { (1991) }\end{array}$ \\
\hline $\begin{array}{l}\text { Potter's Cove } \\
\text { King George Island }\end{array}$ & $8470 \pm 230$ & $\begin{array}{l}\text { Mollusc frag- } \\
\text { ments }\end{array}$ & $\begin{array}{l}\text { Sugden and John } \\
\text { (1973) }\end{array}$ \\
\hline $\begin{array}{l}\text { The Naze } \\
\text { James Ross Island }\end{array}$ & $7360 \pm 100$ & $\begin{array}{l}\text { Mollusc frag- } \\
\text { ments }\end{array}$ & $\begin{array}{l}\text { Hjort and others } \\
\text { (1997) }\end{array}$ \\
\hline $\begin{array}{l}\text { The Naze } \\
\text { James Ross Island }\end{array}$ & $7260 \pm 90$ & Mollusc shells & $\begin{array}{l}\text { Hjort and others } \\
\text { (1997) }\end{array}$ \\
\hline $\begin{array}{l}\text { Walker Point, } \\
\text { Elephant Island }\end{array}$ & $5350 \pm 60$ & Moss peat & $\begin{array}{l}\text { Björck and others } \\
\text { (1991) }\end{array}$ \\
\hline $\begin{array}{l}\text { Lake 35/“Åsa”, Byers } \\
\text { Peninsula, } \\
\text { Livingston Island }\end{array}$ & $4600 \pm 100$ & Limnic moss & $\begin{array}{c}\text { Björck and others } \\
(1993,1996 a)\end{array}$ \\
\hline
\end{tabular}




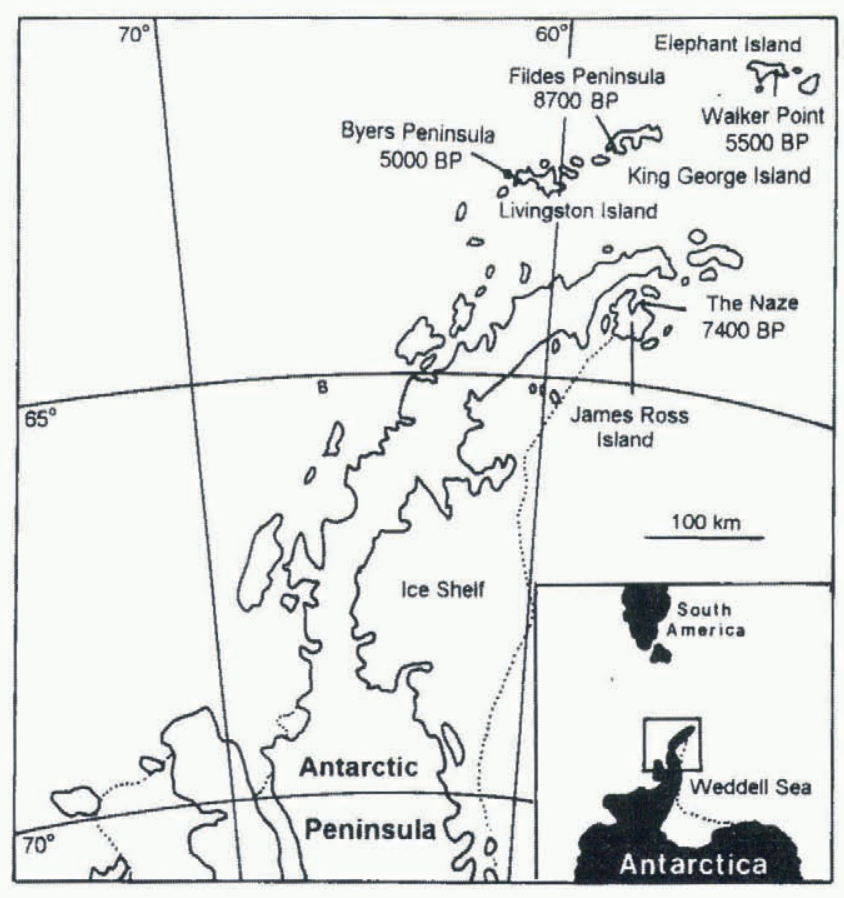

Fig. 1. Map of the northern Antarctic Peninsula region, showing ${ }^{14} \mathrm{C}$ dates regarded as closely postdating the deglaciation in different areas.

\section{THE DEGLAGIATION}

Recently published land-based studies of the post-Last Glacial Maximum deglaciation in the Antarctic Peninsula region are from three main areas: (1) Fildes Peninsula on King George Island (e.g. Mäusbacher, 1991), (2) Byers Peninsula on Livingston Island (e.g. Björck and others, 1996a), both in the South Shetland Islands; and (3) James Ross Island in the western Weddell Sea (Ingólfsson and others, 1992; extended and updated by Hjort and others, 1997). The oldest reliable ${ }^{14} \mathrm{C}$ datings from the region (see under James Ross Island, below) are listed in Table 1 and indicated in Figure 1.

\section{Fildes Peninsula}

The Fildes Peninsula studies (Mäusbacher, 1991, e.g. fig. 72) are based on ${ }^{14} \mathrm{C}$-dated lake-sediment cores. They indicate a slow and gradual deglaciation of this lowland area (the second largest in the South Shetlands, after Byers Peninsula) between about $9000 \mathrm{BP}$ (the oldest dating is about $8700 \mathrm{BP}$; see Table 1) and 5500 BP. During that time, sea level never stood above $22 \mathrm{~m}$, and it took the ice front more than 3000 years to retreat $5 \mathrm{~km}$ ! Around $5000 \mathrm{BP}$ the minerogenic component in the lake sediments distinctly increased. This is interpreted as the result of renewed glacial activity, which lasted until about $4000 \mathrm{BP}$.

Sugden and John's (1973) oldest deglaciation date from the South Shetlands, from nearby Potter's Cove on King George Island (detailed description in John and Sugden, 1971), was taken as evidence for a deglaciation around 9000 BP. However, when using a -1200 years reservoir correction, that date becomes only about $8500 \mathrm{BP}$ (Table 1).

Mäusbacher (1991) also dated a distinct $16 \mathrm{~m}$ shoreline on Fildes Peninsula (part of the 15-20 m main Holocene beach level in the region) to about $6000 \mathrm{BP}$, which roughly fits with the approximately $5400 \mathrm{BP}$ age of the $18 \mathrm{~m}$ level in Potter's Cove obtained when using the -1200 years correction on Clapperton and Sugden's (1988) original date.

\section{Byers Peninsula}

The oldest deglaciation date from Byers Peninsula, about 4600 BP (Björck and others, 1993, 1996a), is also from lake sediments. The cores from this area show that the "postglacial" marine limit here lies below $35 \mathrm{~m}$. Deglaciation proceeded gradually until most of the approximately $6 \mathrm{~km}$ wide (in the direction the glacier withdrew) peninsula was ice-free by about $3000 \mathrm{BP}$, and the retreat was faster than on Fildes Peninsula during the earlier part of the Holocene. The ice front eventually withdrew to somewhere behind its present limit, as shown by a whale bone transported forwards and upwards during the Little Ice Age readvance of the Rotch Dome ice front, and by beach ridges continuing underneath the ice cap (Björck and others, 1996a).

\section{James Ross Island}

A recent critical discussion of deglaciation dates from James Ross Island and surrounding islands in the western Weddell Sea (Hjort and others, 1997) casts doubt on the reliability of two ${ }^{14} \mathrm{C}$ dates with ages between 10000 and 9000 BP. These were made on algal mats and moss from glacier-margin lakes (Zale and Karlén, 1989; Ingólfsson and others, 1992) and may have been contaminated by old carbon from the glacial meltwater. It is suggested (Hjort and others, 1997) that deglaciation of the presently ice-free lowland areas here started only shortly before $7400 \mathrm{BP}$, at a marine level around $30 \mathrm{~m}$. The mid-Holocene "Bahia Bonita" glacial readvance, first described by Rabassa (1983) from Brandy Bay on northern James Ross Island and then ${ }^{14} \mathrm{C}$-dated to about $5000 \mathrm{BP}$, was now found to have culminated at around $4600 \mathrm{BP}$. This was after a non-surge advance of more than $7 \mathrm{~km}$ (Hjort and others, 1997). The advance was contemporaneous with a marine level at 18-16 m. By about $4300 \mathrm{BP}$ the lowlands in Brandy Bay were ice-free again, and from studies of lake sediments Björck and others (1996b) dated the Holocene climatic optimum (a "hypsithermal" period with relatively very warm and humid conditions) to about $4200-3000 \mathrm{BP}$.

A glacial oscillation marked by a set of distinct moraines at Hope Bay, near the tip of the Antarctic Peninsula north of James Ross Island, has been dated to about 4700 BP by Zale (1994).

\section{DISGUSSION AND GONCLUSIONS}

It has not yet been established exactly how far out from the present coastline the glaciers around the Antarctic Peninsula and its surrounding islands reached during the Last Glacial Maximum, partly as a dynamic effect of the lowering of the grounding line with the global eustatic sea-level regression. It can, however, be postulated that when global sea level started to rise again, from about $15000 \mathrm{BP}$ onwards, these glacier fronts gradually retreated (e.g. Pope and Anderson, 1992; Pudsey and others, 1994).

Thus far, parallelism with the Northern Hemisphere is uncontroversial. However, when it comes to the chronology of the deglaciation of the presently ice-free lowland areas, which to a large extent remained above sea level throughout the Holocene, the picture differs much from that in the Northern Hemisphere. It also differs from most Antarctic 
ice-core data interpretations, which have tended to see a strong parallelism with the Greenland ice-core data. In the areas of Antarctica treated in this paper, there seems to have been a gradual, often slow deglaciation, starting at the earliest around $9000 \mathrm{BP}$ and with its first phase not completed until about 5500 BP (Björck and others, 1991; Mäusbacher, 1991). Then came the "Bahia Bonita" glacial readvance, culminating shortly after 5000 BP. This advance was followed by renewed glacial retreat, more rapid in the continental areas of higher equilibrium-line altitude (ELA) in the western Weddell Sea (like James Ross Island) than in the maritime, lower-ELA South Shetlands (such as on Byers Peninsula). Then, about 4000-3000 BP, came the short Antarctic Peninsula region hypsithermal, after which conditions gradually approached the present.

The extended period of rather slow deglaciation during the first half of the Holocene (not unlike what has recently been suggested for the inner parts of the Ross Sea; e.g. Licht and others, 1996) could either indicate a mass-balance situation with increased precipitation during the gradual establishment of Holocene interglacial conditions or simply be due to delayed (as compared with the Northern Hemisphere) warming. The glacial readvance culminating around 5000-4500 BP (also identified along the East Antarctic coast, by Domack and others, 1991) now seems most likely to have been an effect of renewed cooling. Such a colder period, lasting from about 7000 to $4500 \mathrm{BP}$, has recently been identified by Shevenell and others (1996) from marine sediments on the western side of the Antarctic Peninsula.

The final disappearance of glaciers from the lowland areas discussed roughly coincided with the beginning of the brief hypsithermal, which as noted lasted between about 4000 and $3000 \mathrm{BP}$ and was the warmest Holocene period on record in this region (e.g. Björck and others, 1996b; Shevenell and others, 1996). This warm period has also been recorded in the Ross Sea area, where it was expressed by expanding penguin colonisation (Baroni and Orombelli, 1994). It approximately coincided with the peaking of Milankovitchean summer insolation in the south (e.g. Budd and Smith, 1987; Budd and Rayner, 1990), which, especially in the northern Antarctic Peninsula region, was well out of phase with insolation in the Northern Hemisphere.

We thus conclude that the geological ground truth in the Antarctic Peninsula region does not suggest any close chronological correlation with Holocene glacial events in the Northern Hemisphere. Except for the purely eustatically induced changes, glacial developments in this region seem to have been largely out-of-phase with events in the north. An exception was the Little Ice Age.

\section{ACKNOWLEDGEMENTS}

The logistics of the Swedish fieldwork were organised by the Swedish Polar Research Secretariat, and the research was financed by the Swedish Natural Science Research Council and Lund University. The first author's participation in the Hobart "Antarctica and Global Change" meeting was funded by the Royal Physiographic Society in Lund.

\section{REFERENCES}

Baroni, C. and G. Orombelli. 1994. Abandoned penguin rookeries as Holocene paleoclimatic indicators in Antarctica. Geology, 22(1), 23-26.

Björck, S. and 7 others. 1991. Stratigraphic and paleoclimatic studies of a 5,500 years old moss bank on Elephant Island, Antarctica. Arct. Alp. Res., $23(4), 361-374$.

Björck, S., H. Håkansson, S. Olsson, L. Barnekow and J. Janssens. 1993. Paleoclimatic studies in South Shetland Islands, Antarctica, based on numerous stratigraphic variables in lake sediments. J. Paleolimnol., 8(3), 233-272.

Björck, S., C. Hjort, Ó. Ingólfsson, R. Zale and J. Ising. 1996a. Holocene deglaciation chronology from lake sediments. In López-Martínez, J., M. R. A. Thomson and J.W. Thomson, eds. Geomorphological map of Byers Peninsula, Livingston Island. Cambridge, British Antarctic Survey, Sheet 5-A. (Geomap Series.)

Björck, S., S. Olsson, C. Ellis-Evans, H. Håkansson, O. Humlum and J.M. de Lirio. 1996b. Late Holocene palaeoclimatic records from lake sediments on James Ross Island, Antarctica. Palaeogeogr., Palaeoclimatol., Palaeoecol., 121 (3-4), 195-220.

Budd, W. F. and P. Rayner. 1990. Modelling global ice and climate changes through the ice ages. Ann. Glaciol., 14, 23-27.

Budd, W. F. and I. N. Smith. 1987. Conditions for growth and retreat of the Laurentide ice sheet. Géogr. Phys. Quat., 41 (2), 279-290.

Clapperton, C. M. 1990. Quaternary glaciations in the Southern Hemisphere: an overview. Quat. Sci. Rev., 9(2-3), 299-304.

Clapperton, C. M. and D. E. Sugden. 1988. Holocene glacier fluctuations in South America and Antarctica. Quat. Sci. Rev., 7(2), 185-198.

Domack, E.W., A.J.T. Jull and S. Nakao. 1991. Advance of East Antarctic outlet glaciers during the hypsithermal: implications for the volume state of the Antarctic ice sheet under global warming. Geology, 19(11), 1059-1062.

Gordon, J. E. and D. D. Harkness. 1992. Magnitude and geographic variation of the radiocarbon content in Antarctic marine life: implications for reservoir corrections in radiocarbon dating. Quat. Sci. Rev., 11 (7-8), 697-708.

Hjort, C., Ó. Ingólfsson, P. Möller andJ. M. de Lirio. 1997. Holocene glacial history and sea level changes onJames Ross Island, Antarctic Peninsula. f. Quat. Sci., 12 (4), 259-273.

Ingólfsson, Ó., C. Hjort, S. Björck and R. I. L. Smith. 1992. Late Pleistocene and Holocene glacial history of James Ross Island, Antarctic Peninsula. Boreas, 21 (3), 209-222.

John, B. S. and D. E. Sugden. 1971. Raised marine features and phases of glaciation in the South Shetland Islands. Br. Antarct. Surv. Bull. 24, 45-111.

Licht, K. J., A. E. Jennings, J. T. Andrews and K. M. Williams. 1996. Chronology of the late Wisconsin ice retreat from the western Ross Sea, Antarctica. Geology, 24 (3), 223-226.

Mäusbacher, R. 1991. Die Jungkvartäre Relief- und Klimageschichte im Bereich der Fildeshalbinsel, Süd-Shetland-Inseln, Antarktis. Heidelb. Geogr. Arb. 89.

Pope, P. G. and J. B. Anderson. 1992. Late Quaternary glacial history of the northern Antarctic Peninsula's western continental shelf: evidence from the marine record. In Elliot, D.H., ed. Contributions to Antarctic research III. Washington, DC, American Geophysical Union, 63-91. (Antarctic Research Series 57.)

Pudsey, C. J., P. F. Barker and R. D. Larter. 1994. Ice sheet retreat from the Antarctic Peninsula shelf. Continental Shelf Res., 14(15), 1647-1675.

Rabassa, J. 1983. Stratigraphy of the glacigenic deposits in northern James Ross Island, Antarctic Peninsula. In Evenson, E. B., C. Schlüchter and J. Rabassa, eds. Tills and related deposits: genesis/petrology/application/stratigraphy. Rotterdam, A. A. Balkema, 329-340.

Rabassa, J. 1987. Drumlins and drumlinoid forms in northern James Ross Island, Antarctic Peninsula. In Menzies, J. and J. Rose, eds. Drumlin Symposium. Rotterdam, A. A. Balkema, 267-288.

Shevenell, A. E., E.W. Domack and G. M. Kernan. 1996. Record of Holocene paleoclimate change along the Antarctic Peninsula: evidence from glacial marine sediments, Lallemand Fjord. Pap. Proc. R. Soc. Tasmania, $130(2), 55-64$.

Sugden, D. E. and B. S. John. 1973. The age of glacier fluctuations in the South Shetland Islands, Antarctica. In Van Zinderen Bakker, E. M., ed. Palaeoecology of A frica and of the surrounding islands and Antarctica. Vol. 8. Cape Town, A.A. Balkema, $139-159$.

Zale, R. $1994 .{ }^{14} \mathrm{C}$ age corrections in Antarctic lake sediments inferred from geochemistry. Radiocarbon, 36(4), 173-185.

Zale, R. and W. Karlén. 1989. Lake sediment cores from the Antarctic Peninsula and surrounding islands. Geogr. Ann., 71A(3-4), 211-220. 